\title{
High genetic and phenotypic variability of Streptococcus thermophilus strains isolated from artisanal Yuruk yoghurts
}

\author{
Oylum Erkus $^{\mathrm{a}, 1}$, Burcu Okuklu ${ }^{\mathrm{a}, 1}$, Ali F. Yenidunya ${ }^{\mathrm{b}}$, Sebnem Harsa ${ }^{\mathrm{a}, *}$ \\ a Department of Food Engineering, Izmir Institute of Technology, IYTE, Gulbahce Campus, Urla, 35430 Izmir, Turkey \\ ${ }^{\mathrm{b}}$ Department of Medicinal Biology, Cumhuriyet University, Sivas, Turkey
}

\section{A R T I C L E I N F O}

\section{Article history:}

Received 31 May 2012

Received in revised form

11 February 2013

Accepted 9 March 2013

Available online 8 April 2013

\section{Keywords:}

Streptococcus thermophilus

Yoghurt

Fingerprinting

PFGE

Starter

\begin{abstract}
A B S T R A C T
Streptococcus thermophilus is a commonly used starter bacterium in dairy industry. It reduces the $\mathrm{pH}$ of milk rapidly and equilibrates the medium for the growth of Lactobacillus delbrueckii subsp. bulgaricus during yoghurt fermentation. Efforts to increase the diversity of artisanal yoghurt starters are not only important to bring new strains with novel and desirable characteristics, but also for the preservation of natural diversity which diminishes with the overuse and spread of industrial starters to natural resources. In the present study, 14 artisanal yoghurt samples were processed for the isolation of promising strains for yoghurt starter culture production and 66 strains were subsequently characterized. They were all identified as $S$. thermophilus using species-specific PCR and 16S rRNA gene sequencing. Genotypic diversity at the strain level was investigated by pulsed field gel electrophoresis (PFGE), and 22 homology groups were obtained. Further phenotypic characterization unearthed a significant phenotypic heterogeneity within homology groups, mostly with atypical novel character. Only 7 out of 66 strains showed S. thermophilus type-strain like phenotypic traits. Majority of the isolates were determined to be protease positive and fast milk acidifier to be used as yoghurt starter culture.
\end{abstract}

(c) 2013 Elsevier Ltd. All rights reserved.

\section{Introduction}

Yoghurt is a fermentation product produced by the protocooperative action of two homofermentative bacteria, Streptococcus thermophilus and Lactobacillus delbrueckii subsp. bulgaricus. Traditionally, it has been used as a preservation technique for milk by the nomadic people living in the Middle East (Tamime \& Robinson, 1985a). The interaction between two species has been shown to be related to purine, amino acid, and short chain fatty acid metabolisms by transcriptome and proteome analyses of co-culture fermentations (Herve-Jimenez et al., 2008; Sieuwerts, 2009, 221p). During mixed growth, S. thermophilus supplies $\mathrm{CO}_{2}$, folic and formic acids to L. delbrueckii subsp. bulgaricus, which in turn provides the essential amino acids with its high proteolytic activity to S. thermophilus (Sieuwerts, 2009, 221p). Within this co-culture fermentation, $S$. thermophilus is the initiator bacterium with its ability to lower the $\mathrm{pH}$ rapidly to the natural milk acidity, and robust S. thermophilus strains are primary for industrial production.

\footnotetext{
* Corresponding author. Tel.: +90 232 7506291; fax: +90 2327506196.

E-mail address: sebnemharsa@iyte.edu.tr (S. Harsa).

$1 \mathrm{OE}$ and BO equally contributed to this study.
}

The consistency needed for industrial production demands the use of defined $S$. thermophilus strains with known physiological, biochemical and genotypic characteristics. On the other hand, the overuse of these limited defined cultures decrease the biodiversity of yoghurt starter bacteria in natural reserves, and leads to severe phage predation problems in industrial yoghurt fermentations. Therefore, continuous isolation and characterization of new starter strains offering alternative flavor and texture properties, and a broad phage resistance spectrum against the phage attacks become necessary. Anatolian region, where the traditional yoghurt backsloping is still very common, is a rich source of these novel starter candidates for dairy industry, and selected as an isolation region for this study.

Identification is not very straightforward for $S$. thermophilus. Loss or gain of metabolic functions for $S$. thermophilus has been observed frequently (Gobbetti \& Corsetti, 1999; Pearce \& Flint, 1999; Tamime \& Robinson, 1985b), and atypical characters are common for artisanal strains (Millière, Abidi, \& Lefebvre, 1996). Identification studies indicate high phenotypic heterogeneity in natural microflora (Giraffa, Paris, Valcavi, Gatti, \& Neviani, 2001). Therefore, biochemical identification techniques should be coupled to a reliable taxonomic marker at species level such as $16 \mathrm{~S}$ rDNA, and to a high resolution fingerprinting technique for strain 
differentiation. Among fingerprinting techniques pulsed field gel electrophoresis (PFGE), repetitive PCR (REP-PCR), and amplified fragment length polymorphisms (AFLP) have often produced reproducible results with high resolutions (Giraffa \& Rossetti, 2005; Moschetti, Blaiotta \& Aponte, 1998; Rademaker et al., 2007; Salzano, Moschetti, Villani, \& Coppola, 1993).

In this study, novel $S$. thermophilus strains were aimed to be isolated from artisanal yoghurts produced by Yuruk people along Taurus Mountains. Species-specific PCR (Giraffa \& Rossetti, 2005; Lick, Keller, Bockelmann, \& Heler, 1995) was used for taxonomic identification of $S$. thermophilus isolates. Fingerprinting was carried out by PFGE to investigate the genotypic diversity at the strain level. Phenotypic characterization indicated even more heterogeneity in the same homology groups and revealed atypical phenotypes. Furthermore, the isolates were evaluated for their technological performances such as milk acidification and proteolysis to be used as yoghurt starter bacteria.

\section{Materials and methods}

\subsection{Reference strains and sampling of artisanal yoghurts}

S. thermophilus CCM 4757 reference strain was taken from Czech Collection of Microorganisms (CCM). As an isolation source, in total 14 artisanal yoghurt samples were collected from the villages of Taurus region that are located far from city centers to minimize the contamination risk with commercial starter cultures.

\subsection{Isolation and preservation}

Ten milliliters of samples were homogenized in $90 \mathrm{~mL} 1 \mathrm{~g} /$ $100 \mathrm{~mL}$ peptone water. Dilutions up to $10^{-8}$ were prepared and $1 \mathrm{~mL}$ aliquots from $10^{-5}, 10^{-6}$, and $10^{-7}$ dilutions were spread onto agar plates containing M17 selective medium (pH 6.8) (Terzaghi \& Sandine, 1975). The plates were incubated at $42{ }^{\circ} \mathrm{C}$ for 3 days under microaerophilic conditions. The plates with colony forming units (CFU) of 30-300 were used for S. thermophilus isolation. Isolated bacteria were enriched in M17 broths, purified using the streak plate technique, and further stored in $20 \mathrm{~mL} / 100 \mathrm{~mL}$ glycerol-M17 medium at $-80^{\circ} \mathrm{C}$.

\subsection{Biochemical identification}

Morphology and arrangement of the cells were determined by microscopic examination after Gram staining. Additionally, the isolates were screened for catalase activity using $3 \mathrm{~mL} / 100 \mathrm{~mL}$ $\mathrm{H}_{2} \mathrm{O}_{2}$. Gram positive and catalase negative isolates were identified as lactic acid bacteria (LAB) and used for further analysis.

Gas production from glucose, growth at $10{ }^{\circ} \mathrm{C}$ and $45^{\circ} \mathrm{C}$, ability to grow at $2 \mathrm{~g} / 100 \mathrm{~mL}$ and $4 \mathrm{~g} / 100 \mathrm{~mL} \mathrm{NaCl}$ salt concentration tests were performed for the species identification, and the following carbohydrate fermentation tests were performed to determine the phenotypic variability: $\mathrm{L}(+)$ arabinose, $\mathrm{D}(+)$ galactose, lactose, maltose, mannitol, raffinose, sucrose, D $(-)$ salicin, sorbitol, D $(+)$ trehalose, D (+) xylose, glycerol, D (+) mannose, D (-) ribose, melibiose, melezitose, glucose, fructose, and rhamnose (Bulut et al., 2005).

\subsection{Genotypic identification and fingerprinting}

\subsubsection{Genomic DNA extraction}

Genomic DNA samples were prepared as published before (Bulut et al., 2005), and stored at $-20^{\circ} \mathrm{C}$.

\subsubsection{Identification by species-specific PCR and 16 rRNA gene sequencing}

The isolated strains were first identified by species-specific PCR and the 16S rRNA gene of one representative isolate was sequenced for verification. Species-specific PCR was based on the amplification of an intragenic fragment of 968 bp within the lacZ gene of S. thermophilus (Lick et al., 1995). Primers used for the amplification were 5'- CAC TAT GCT CAG AAT ACA - $3^{\prime}$ and 5'- CGA ACA GCA TTG ATG TTA $-3^{\prime}$ for forward and reverse strand respectively.

For the PCR, $50 \mathrm{ng}$ genomic DNA as the template, $0.2 \mathrm{mmol} / \mathrm{L}$ dNTPs (Fermentas), $1.5 \mathrm{mmol} / \mathrm{L} \mathrm{MgCl}_{2}, 10 \mathrm{pmol}$ each of the primers, 1.25 units of Taq DNA polymerase ( $5 \mathrm{U} / \mu \mathrm{L}$, Fermentas) and $5 \mu \mathrm{L}$ $\mathrm{Mg}^{2+}$ free Taq DNA polymerase buffer were combined in a $50 \mu \mathrm{L}$ final reaction volume. PCR amplification conditions included $300 \mathrm{~s}$ initial denaturation step at $94{ }^{\circ} \mathrm{C}, 40$ amplification cycles $(60 \mathrm{~s}$ denaturation at $94{ }^{\circ} \mathrm{C}, 60 \mathrm{~s}$ annealing at $46{ }^{\circ} \mathrm{C}, 60 \mathrm{~s}$ elongation at $72{ }^{\circ} \mathrm{C}$ ), and $6000 \mathrm{~s}$ final extension at $72{ }^{\circ} \mathrm{C}$. S. thermophilus CCM 4757 DNA was used as template for positive control reactions.

For the verification of species-specific PCR results, 16S rRNA gene of representative isolate, cTY17, was sequenced in an ABI 310 DNA Sequencer at the Central Laboratory of Middle East Technical University. The 16S rRNA gene amplification product was sequenced in both directions using two external primers; $5^{\prime}$ - AGA GTT TGA TCC TGG CTC AG $-3^{\prime}$ and $5^{\prime}$ - AGG GTT GCG CTC GTT G $-3^{\prime}$, and two inner primers; $5^{\prime}$ - CTA CGG CTA CCT TGT TAC CA $-3^{\prime}$ and $5^{\prime}-$ GTG CCA GCA GCC GCG GTA A - $3^{\prime}$.

\subsubsection{Pulsed field gel electrophoresis analysis}

PFGE samples were prepared according to the protocol as published before (Okuklu, 2005, pp. 33-35). Bacterial cultures were activated overnight in $10 \mathrm{~mL}$ of MRS broth at $42{ }^{\circ} \mathrm{C}$. Cells from $300 \mu \mathrm{L}$ culture were harvested by centrifugation (Hettich Universal Zentrifugen, $320 \mathrm{R})$ at $10,000 \times \mathrm{g}$ for $5 \mathrm{~min}$, and washed in TrisEDTA Buffer (10 mmol/L Tris, pH 7.0, $20 \mathrm{mmol} / \mathrm{L} \mathrm{NaCl}, 50 \mathrm{mmol} / \mathrm{L}$ EDTA, pH 8.0). Cell pellet were resuspended in $100 \mu \mathrm{L}$ of the same buffer, mixed with $100 \mu \mathrm{L}$ of $2 \mathrm{~g} / 100 \mathrm{~mL}$ low melting temperature agarose (Applichem) at $50{ }^{\circ} \mathrm{C}$, dispensed into the plug wells, and stored at $4{ }^{\circ} \mathrm{C}$ for $30 \mathrm{~min}$. The plugs were taken to $1 \mathrm{~mL}$ lysozyme solution (30 mmol/L Tris, pH 8.0, $50 \mathrm{mmol} / \mathrm{L} \mathrm{NaCl}, 5 \mathrm{mmol} / \mathrm{L}$ EDTA, $\mathrm{pH} 8.0,10 \mathrm{mg} / \mathrm{mL}$ lysozyme) for lysis at $37^{\circ} \mathrm{C}$ for $4 \mathrm{~h}$, and washed with $5 \mathrm{~mL}$ washing buffer (20 mmol/L Tris, pH 8.0, $50 \mathrm{mmol} / \mathrm{L}$ EDTA, $\mathrm{pH} 8.0$ ) for $45 \mathrm{~min}$ with gentle agitation. Subsequently the plugs were incubated in $1 \mathrm{~mL}$ of proteinase $\mathrm{K}$ solution (100 mmol/L EDTA, $\mathrm{pH}$ 8.0, $0.2 \mathrm{~g} / 100 \mathrm{~mL}$ sodium deoxycholate, $1 \mathrm{~g} / 100 \mathrm{~mL}$ sodium $\mathrm{N}$ laurylsarcosine, $1 \mathrm{mg} / \mathrm{mL}$ proteinase $\mathrm{K}$ ) at $50{ }^{\circ} \mathrm{C}$ overnight and washed twice in washing buffer for $45 \mathrm{~min}$ with gentle agitation, transferred into PMSF buffer $(20 \mathrm{mmol} / \mathrm{L}$ Tris, pH 8.0, $50 \mathrm{mmol} / \mathrm{L}$ EDTA, pH 8.0, $1 \mathrm{mmol} / \mathrm{L}$ PMSF) for $45 \mathrm{~min}$ and taken to the final wash in 10 times diluted washing buffer before restriction.

For the digestion, genomic DNA containing agarose plugs were equilibrated in $1 \mathrm{~mL} 1 \times$ Smal buffer for $1 \mathrm{~h}$ with gentle agitation and digested with 30 units of SmaI at $30{ }^{\circ} \mathrm{C}$ overnight, and equilibrated in $1 \mathrm{~mL}$ of $0.5 \times$ TBE buffer for $1 \mathrm{~h}$ prior to electrophoresis. The agarose plugs were inserted into the wells of $1 \mathrm{~g} / 100 \mathrm{~mL}$ PFGE grade agarose gel (Bio-Rad) that was immersed in $0.5 \times$ TBE buffer. The wells were covered with low melting temperature agarose. Electrophoresis was performed in a CHEF DRII system (Bio-Rad, California, USA) with $5.3-34.9$ pulse times at $6 \mathrm{~V} / \mathrm{cm}$ at $14{ }^{\circ} \mathrm{C}$ for $20 \mathrm{~h}$. In the end of electrophoresis run, the gel was stained in $600 \mathrm{~mL} \mathrm{dH} \mathrm{H}_{2} \mathrm{O}$ containing $2 \mathrm{mg} / 100 \mathrm{~mL}$ of ethidium bromide for $45 \mathrm{~min}$, and visualized in a gel documentation system (Vilber Lourmat, France). For cluster analysis, the similarity among profiles was calculated on the basis of the Dice's coefficient. The dendrogram was constructed according to the unweighted pair group method with arithmetic averages clustering algorithm (UPGMA). 


\subsection{Technological performance assays}

\subsubsection{Milk acidifying activity}

The isolates were incubated in M17 broth at $42{ }^{\circ} \mathrm{C}$ for overnight activation. $200 \mathrm{~mL}$ batches of $10 \mathrm{~g} / 100 \mathrm{~mL}$ skimmed milk containing $1 \mathrm{~g} / 100 \mathrm{~mL}$ yeast extract were inoculated (1\%) with the propagated cultures, and incubated at $42{ }^{\circ} \mathrm{C}$ for $6 \mathrm{~h}$. The $\mathrm{pH}$ of the samples was determined every hour using a $\mathrm{pH}$ meter (Metrohm $744 \mathrm{pH}$ meter, Switzerland). S. thermophilus isolates reaching to the $\mathrm{pH}$ range of 4.60-4.70 within $5 \mathrm{~h}$ of incubation were selected as promising candidates for yoghurt fermentation. The isolates that could not reduce the $\mathrm{pH}$ of skimmed milk to 4.6 within $6 \mathrm{~h}$ were further incubated until the $\mathrm{pH}$ values reached to 4.6 , and the times required for this $\mathrm{pH}$ reduction were determined.

\subsubsection{Proteolytic activity}

The proteolytic activity of $S$. thermophilus isolates was determined on agar plates prepared as described previously (Dandoy et al., 2011) with the following modifications. The agar medium contained $1.5 \mathrm{~g} / 100 \mathrm{~mL}$ agar, $1.9 \mathrm{~g} / 100 \mathrm{~mL}$ Sodium glycerophosphate, and $5 \mathrm{~g} / 100 \mathrm{~mL}$ skimmed milk powder. $0.01 \mathrm{~g} / 1000 \mathrm{~mL}$ bromocresol purple was added as acidity indicator for growth. The isolates were propagated in M17 broth at $42{ }^{\circ} \mathrm{C}$ for overnight, plated on agar plates, and incubated at $37{ }^{\circ} \mathrm{C}$ for $72 \mathrm{~h}$. If the colonies appeared as opaque, big and yellow, the isolate was classified as protease positive, however if the colonies appeared as small, white and translucent, the isolate was considered to be protease negative.

\section{Results and discussion}

\subsection{Isolation and biochemical identification}

In total 200 isolates were obtained from 14 artisanal yoghurt samples. After the elimination of poorly growing cells during subcultivations, 66 of the isolates (obtained from 11 of the 14 yoghurt samples) were selected and used for the biochemical characterization. The isolates were determined to be Gram positive, homofermentative, catalase negative, and with spherical or ovoid morphology appearing as pairs or chains (Fig. 1). Only two of the isolates, c97-2 and cTY44, were found to grow in $2 \mathrm{~g} / 100 \mathrm{~mL} \mathrm{NaCl}$, and none of them were able to grow at $4 \mathrm{~g} / 100 \mathrm{~mL} \mathrm{NaCl}$.

Carbohydrate utilization profiles were the most differentiative phenotypic information for the isolates. In total, 22 different profiles were obtained in our study (Table 1). Several studies documented that $S$. thermophilus strains can yield varying carbohydrate

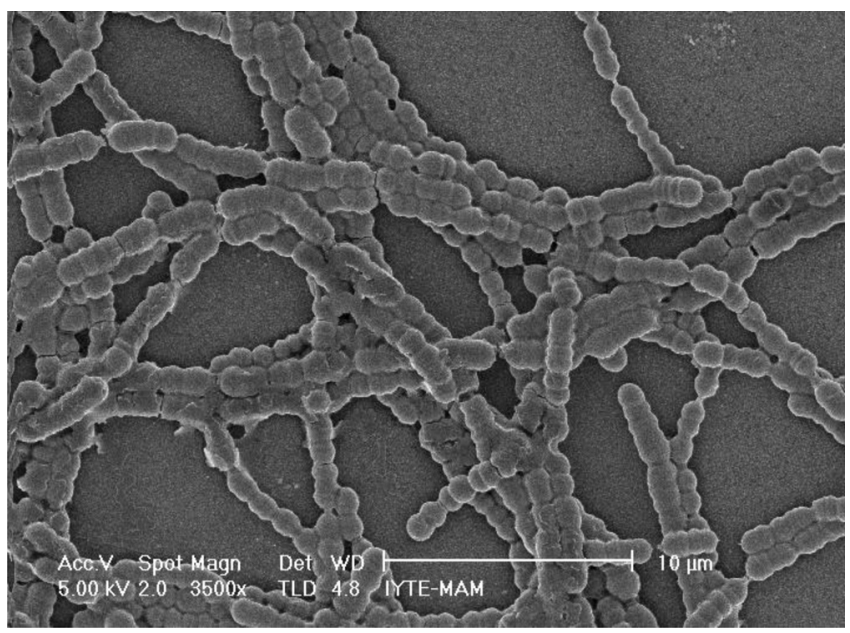

Fig. 1. A Scanning Electron Microscopy image of isolate cTY17. utilization profiles (Gobbetti \& Corsetti, 1999; Robinson, 2002; Zirnstein \& Hutkins, 1999). Utilization of glucose, lactose and fructose by $S$. thermophilus isolates were found to be a common characteristic in all studies, while mannose, galactose, sucrose, maltose, melibiose, and raffinose utilizations were giving variable profiles. Therefore, the isolates that utilize glucose, lactose and fructose, but variable for the rest of the carbohydrates indicated above were phenotypically identified as $S$. thermophilus. According to this reference criterion, 7 of the 66 isolates were assigned as S. thermophilus. The remaining isolates were assigned as atypical (Table 1), and the species name could not be assigned based on phenotypes.

The most prominent atypical profile was of galactose and fructose utilization. Although $S$. thermophilus is known to be fructose positive and galactose negative, 52 out of 66 isolates were found to be fructose negative, and 41 out of 66 were determined to be galactose positive. Galactose positive $S$. thermophilus strains are technologically important, since they can inhibit the growth of undesirable lactic acid bacteria, and prevent the browning defects (Giraffa et al., 2001). Additionally, they have often been the targets for metabolic engineering studies for enhancing the exopolysaccharide (EPS) biosynthesis (Levander, Svensson, \& Radström, 2002). Several explanations were proposed for Gal (+) phenotype in the literature. One explanation attributed it to a deficient promoter that could lead to low expression level of Leloir pathway enzymes for galactose utilization (Bogaard, 2002, pp. 158; Vaughan, Van Der Bogaard, Catzeddu, Kuipers \& de Vos, 2001). The authors explained this finding by characterizing the mutant galactose positive $S$. thermophilus strain and demonstrated the point mutations in the promoter region of Gal operon, which enhances the strength of the promoter. In another study, the low level of galactokinase activity in Gal (-) strains with respect to Gal (+) strains indicated a poor galK translation, which was related to nucleotide differences in ribosome binding site (De Vin, Radstörm, Herman \& de Vuyst, 2005; Vaillancourt et al., 2004). The galactose positive phenotype of our isolated strains could also be due to similar mutations in the promoter region or Shine Dalgarno sequences of Gal operon, and it requires further genetic characterization.

\subsection{Genotypic identification and fingerprinting}

Species-specific PCR was based on the amplification of a $968 \mathrm{bp}$ intragenic fragment within the lac $Z$ gene sequence of $S$. thermophilus. All of the isolates yielded this expected size of amplicons. Results of the species-specific PCR were also verified by sequencing the 16S rRNA gene of one representative isolate (cTY17). 16S rRNA gene sequence (1460 bp) was determined and deposited to Gene Bank with the accession number of EU694138. BLAST analysis indicated 98\% homology to S. thermophilus LMD-9, S. thermophilus LMG 18311, and to S. thermophilus CNRZ1066.

Fingerprinting was succeeded with PFGE analysis. 61 S. thermophilus isolates yielded 22 homology groups, each representing a distinct restriction profile (Fig. 2). Isolates with identical restriction profiles were placed in the same homology group. The reference strain had a unique restriction profile, and was given a unique homology group number. 5 isolates out of 66 were excluded from this work because of their poor DNA preparation quality. The isolates were grouped into three main clusters (A, B and C) at 70\% similarity cut-off. Cluster B included 17 homology groups consisting of 44 isolates, while cluster A contained 5 homology groups including 16 isolates. The isolate cTY53 formed a homology group on its own (cluster C), and has the most distantly related profile.

Isolates from each yoghurt sample had their own distinct PFGE profiles (except for group 15), indicating that they are unique for the yoghurts where they belong to. This might be due to the 
Table 1

Grouping of the isolates based on carbohydrate utilization profiles.

\begin{tabular}{|c|c|c|c|c|}
\hline Group & Count & Carbohydrates Utilized & Atypical Character & Phenotypic Assignment \\
\hline A & 1 & Glucose, Lactose, Sucrose, Mannose & Fructose(-) & Streptococcus sp. \\
\hline B & 17 & Glucose, Lactose, Sucrose, Galactose & Fructose(-) & Streptococcus sp. \\
\hline $\mathrm{C}$ & 12 & Glucose, Lactose, Sucrose & Fructose(-) & Streptococcus sp. \\
\hline $\mathrm{D}$ & 9 & Glucose, Lactose, Galactose & Fructose(-) & Streptococcus sp. \\
\hline$E^{a}$ & 3 & Glucose, Lactose, Sucrose, Fructose & - & S. thermophilus \\
\hline $\mathrm{F}$ & 5 & Glucose, Lactose & Fructose(-) & Streptococcus sp. \\
\hline G & 1 & Lactose, Fructose & Glucose (-) & Streptococcus sp. \\
\hline $\mathrm{H}$ & 1 & Lactose, Galactose & Glucose(-), Fructose(-) & Streptococcus sp. \\
\hline I & 1 & Lactose, Sucrose, Galactose & Glucose(-), Fructose(-) & Streptococcus sp. \\
\hline $\mathrm{J}$ & 2 & Lactose, Sucrose & Glucose(-), Fructose(-) & Streptococcus sp. \\
\hline $\mathrm{K}$ & 1 & Lactose, Sucrose, Fructose & Glucose $(-)$ & Streptococcus sp. \\
\hline $\mathrm{L}$ & 1 & Glucose, Lactose, Fructose, Sucrose, Galactose, Melezitose, Maltose & Melezitose $(+)$ & Streptococcus sp. \\
\hline M & 1 & Glucose, Lactose, Sucrose, Galactose, Melezitose & Fructose(-), Melezitose $(+)$ & Streptococcus sp. \\
\hline $\mathrm{N}$ & 2 & Glucose, Lactose, Sucrose, Galactose, Mannose & Fructose(-) & Streptococcus sp. \\
\hline $\mathrm{O}^{\mathrm{a}}$ & 3 & Glucose, Lactose, Sucrose, Galactose, Fructose, Mannose & - & S. thermophilus \\
\hline $\mathrm{P}$ & 1 & Glucose, Lactose, Sucrose, Galactose, Melezitose, Melibiose, Mannitol & Fructose(-), Melezitose(+), Mannitol(+) & Streptococcus sp. \\
\hline $\mathrm{R}$ & 1 & Glucose, Lactose, Sucrose, Galactose, Fructose, Mannose, Melezitose & Melezitose $(+)$ & Streptococcus sp. \\
\hline $\mathrm{S}$ & 1 & Glucose, Lactose, Sucrose, Galactose, Fructose, Melezitose, Glycerol & Melezitose(+), Glycerol(+) & Streptococcus sp. \\
\hline $\mathrm{T}^{\mathrm{a}}$ & 1 & Glucose, Lactose, Sucrose, Galactose, Fructose & - & S. thermophilus \\
\hline $\mathrm{U}$ & 1 & Glucose, Lactose, Sucrose, Galactose, Fructose, Mannose, Melezitose, Glycerol & Melezitose $(+)$, Glycerol(+) & Streptococcus sp. \\
\hline $\mathrm{Y}$ & 1 & $\begin{array}{l}\text { Glucose, Lactose, Sucrose, Galactose, Fructose, Melezitose, Ribose, Salisin, } \\
\text { Trehalose, Glycerol }\end{array}$ & $\begin{array}{l}\text { Melezitose }(+), \text { Ribose }(+), \text { Salisin }(+) \\
\text { Trehalose }(+), \text { Glycerol }(+)\end{array}$ & Streptococcus sp. \\
\hline
\end{tabular}

a The strains that were able to utilize glucose, lactose, fructose but have variable response for mannose, galactose, sucrose, maltose, melibiose, and raffinose, are phenotypically assigned as typical $S$. thermophilus and highlighted as red in the table.

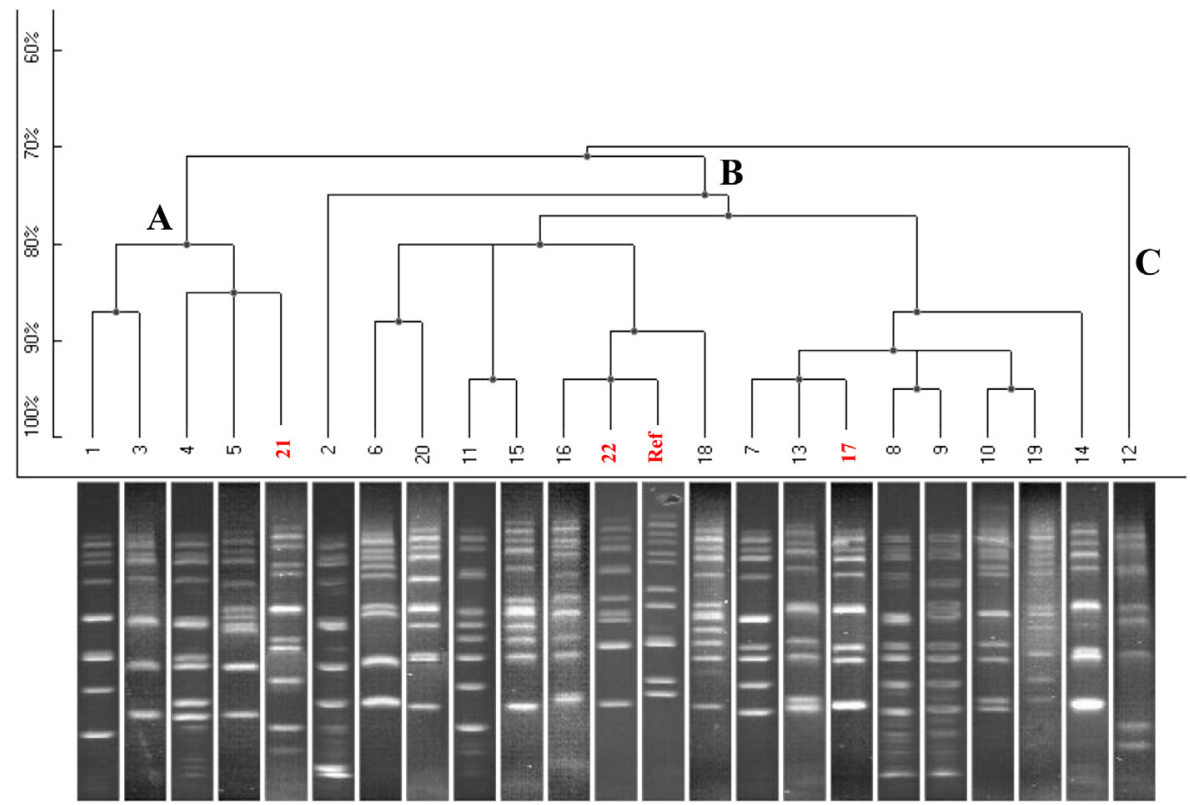

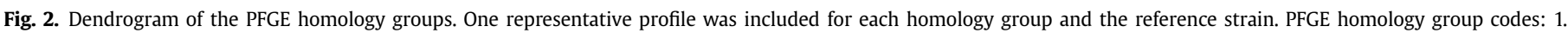

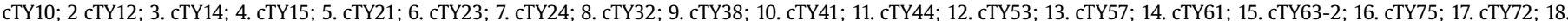

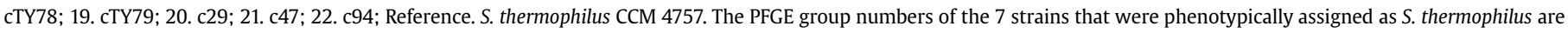
highlighted with red. (For interpretation of the references to color in this figure legend, the reader is referred to the web version of this article.) 
geographical separation and the evolution of their population for that particular niche. As an exception, the homology group 15 was shared by yoghurt samples TY9, TY10 and TY11, which were taken from villages located close to each other (data not given). The highest PFGE profile similarity (95\% similarity) was found between the isolates of yoghurt samples TY5 and TY6 (homology groups 8 and 9), and between the isolates of yoghurt samples TY6 and TY11 (homology groups 10 and 19). Interestingly, the lowest PFGE profile similarity (71\%, between homology groups $11 \& 12$ ) was obtained from isolates that belong to the same yoghurt sample TY7.

The fermentation profile $\mathrm{B}$ was the most common profile and shared by the PFGE homology groups 20, 21,1,11,14,15,16 and 18 (Table 2). On the other hand, isolates from yoghurt sample M7 had identical PFGE patterns (homology group 21), but they showed 8 different fermentation profiles. This was also the case for the isolates of sample M8, which had 7 different fermentation profiles but identical PFGE patterns (homology group 22). These results revealed a high degree of phenotypic variability among isolates that shared the same genotype and suggest that genotypes are not necessarily indicative of a unique ecotype. PFGE might still have resolution limitation to differentiate the isolates with different phenotypic traits (Lortal, Rouault, Guezenee, \& Gautier, 1997; Yeung, Kitts, Cano, Tong, \& Sanders, 2004).

\subsection{Technological performances of the isolates}

The most important criteria for the use of $S$. thermophilus as a starter culture in yoghurt production is rapid acidification in milk, and starter cultures are expected to decrease the $\mathrm{pH}$ of the milk to 4,6 that is the isoelectric point of casein micelles. S. thermophilus is known to be auxotrophic for several amino acids and the concentrations of these essential amino acids in milk are below the requirements of $S$. thermophilus for high cell density growth (Letort \& Juillard, 2001). High density growth of $S$. thermophilus as well as rapid acidification in milk is dependent on its proteolytic activity (Letort, Nardi, Garault, Monnet, \& Juillard, 2002). Therefore, S. thermophilus strains isolated in this study were further studied both for their milk acidification capacity and proteolysis.19 out of 66 S. thermophilus strains decreased the $\mathrm{pH}$ of the milk below 4.6 within $5 \mathrm{~h}$ (Fig. 3), and 18 of 19 (except cTY38) fast acidifying isolates were determined to be protease positive as expected. The rest of the isolates either needed more than $5 \mathrm{~h}$ to reduce the $\mathrm{pH}$ to 4.6 , or they didn't coagulate the milk at all.

Some of the fast acidifying and protease positive $S$. thermophilus strains (c95-1, cTY24, cTY47, cTY55, cTY63-2) have also been studied for their co-culture growth (yoghurt fermentation) in combination with artisanal $L$. delbrueckii subsp. bulgaricus strains and the resulting yoghurt samples were analyzed for flavor formation by Çelik (2007, pp. 78). S. thermophilus and L. delbrueckii subsp. bulgaricus strains were shown to be stably maintained in all combinations $\left(10^{8}-10^{9} \mathrm{cfu} / \mathrm{mL}\right.$ for each species at the end of yoghurt fermentation), and the acetaldehyde, ethanol, acetone, diacetyl and MEK contents of the yogurts were reported to be between 13.44 and $25.44 \mathrm{mg} / \mathrm{L}, 1.49-7.02 \mathrm{mg} / \mathrm{L}, 0.28-0.54 \mathrm{mg} / \mathrm{L}, 0.43-1.79 \mathrm{mg} / \mathrm{L}$, and $0.04-0.11 \mathrm{mg} / \mathrm{L}$, respectively. Acetaldehyde is considered to be the most important compound for the typical yogurt flavor (Gardini, Lanciotti, Guerzoni, \& Torriani, 1999), and generally found between 17 and $41 \mathrm{mg} / \mathrm{L}$ in yoghurts (Abrahamsen, Svensen, \& Tufto, 1978; Tamime \& Deeth, 1980). Çelik (2007) indicated that 11 among 20 different yogurt combinations showed acetaldehyde production over $20 \mathrm{mg} / \mathrm{L}$ and the combination cTY63-2/b22 had the highest acetaldehyde content $(25.444 \mathrm{mg} / \mathrm{L})$. Diacetyl is known to be related to butter-like flavor (Bottazzia \& Dellaglioa, 1967) and detected in large amounts by the combination c95-1/b22. The yoghurts produced with 20 different culture combinations were shown to vary widely for the amount of the flavor compounds offering alternative solutions to meet the different flavor demands of the consumers such as butter-like or sour.

Table 2

Grouping of isolates According to PFGE patterns and sugar fermentation profile.

\begin{tabular}{|c|c|c|c|c|c|c|c|}
\hline $\begin{array}{l}\text { Yoghurt } \\
\text { Sample }\end{array}$ & Isolate Code & $\begin{array}{c}\text { PFGE } \\
\text { Homology G. }\end{array}$ & $\begin{array}{c}\text { Phenotypic } \\
\text { Group }\end{array}$ & $\begin{array}{l}\text { Yoghurt } \\
\text { Sample }\end{array}$ & Isolate Code & $\begin{array}{c}\text { PFGE } \\
\text { Homology G. }\end{array}$ & $\begin{array}{c}\text { Phenotypic } \\
\text { Group }\end{array}$ \\
\hline M5 & $\begin{array}{l}\text { c28, c38 } \\
\text { c39a }\end{array}$ & $\begin{array}{l}20 \\
20 \\
\end{array}$ & $\begin{array}{l}\mathbf{B} \\
\mathbf{M} \\
\end{array}$ & TY6 & $\begin{array}{l}\text { cTY38 } \\
\text { cTY41 }\end{array}$ & $\begin{array}{c}9 \\
10 \\
\end{array}$ & $\begin{array}{l}\text { H } \\
\text { D }\end{array}$ \\
\hline M7 & $\begin{array}{l}\mathrm{c} 47 \\
\mathrm{c} 50 \\
\mathrm{c} 60^{\mathrm{a}}, \mathrm{c} 62^{\mathrm{a}} \\
\mathrm{c} 65 \\
\mathrm{c} 66 \mathrm{a} \\
\mathrm{c} 71 \\
\mathrm{c} 66 \mathrm{~b} \\
\mathrm{c} 52\end{array}$ & $\begin{array}{l}21 \\
21 \\
21 \\
21 \\
21 \\
21 \\
21 \\
-\end{array}$ & $\begin{array}{l}\mathbf{N} \\
\mathbf{B} \\
\mathbf{O} \\
\mathbf{J} \\
\mathbf{Y} \\
\mathbf{U} \\
\mathbf{V} \\
\mathbf{A}\end{array}$ & M8 & $\begin{array}{l}\text { c74 } \\
\text { c77a, c77b, c94a, c95-1, c97-1 c97-2 } \\
\text { c78 } \\
\text { c79 } \\
\text { c85 } \\
\text { c90b }, \text { c94 } \\
\text { c95-2 }\end{array}$ & $\begin{array}{l}22 \\
22 \\
22 \\
22 \\
22 \\
22 \\
22\end{array}$ & $\begin{array}{l}\text { T } \\
\mathbf{C} \\
\text { O } \\
\text { S } \\
\text { K } \\
\mathbf{E} \\
\mathbf{R}\end{array}$ \\
\hline TY5 & $\begin{array}{l}\text { cTY24, cTY25, cTY27 } \\
\text { cTY29,cTY31 } \\
\text { cTY26 } \\
\text { cTY32 } \\
\text { cTY30 }\end{array}$ & $\begin{array}{l}7 \\
7 \\
- \\
8 \\
-\end{array}$ & $\begin{array}{l}\text { D } \\
\text { F } \\
\text { F } \\
\text { D } \\
\text { B }\end{array}$ & TY11 & $\begin{array}{l}\text { cTY75 } \\
\text { cTY77 } \\
\text { cTY78 } \\
\text { cTY82 } \\
\text { cTY79 } \\
\text { cTY81 }\end{array}$ & $\begin{array}{l}16 \\
15 \\
18 \\
18 \\
19 \\
-\end{array}$ & $\begin{array}{l}\text { B } \\
\text { B } \\
\text { B } \\
\text { P } \\
\text { J } \\
\text { L }\end{array}$ \\
\hline TY2 & $\begin{array}{l}\text { cTY8 } \\
\text { cTY9, cTY10 } \\
\text { cTY12 } \\
\text { cTY14 } \\
\text { cTY15, cTY17 } \\
\end{array}$ & $\begin{array}{l}1 \\
1 \\
2 \\
3 \\
4\end{array}$ & $\begin{array}{l}\text { B } \\
\text { C } \\
\text { D } \\
\text { D } \\
\text { D }\end{array}$ & TY9 & $\begin{array}{l}\text { cTY55, cTY62 } \\
\text { cTY61, cTY63 } \\
\text { cTY57 } \\
\text { cTY63-2 }\end{array}$ & $\begin{array}{l}14 \\
14 \\
13 \\
15\end{array}$ & $\begin{array}{l}\text { B } \\
\text { C } \\
\text { C } \\
\text { I }\end{array}$ \\
\hline TY4 & $\begin{array}{l}\text { cTY20, cTY21 } \\
\text { cTY23 }\end{array}$ & $\begin{array}{l}5 \\
6\end{array}$ & $\begin{array}{l}\mathbf{F} \\
\mathbf{G}\end{array}$ & TY7 & $\begin{array}{l}\text { cTY } 44, \text { cTY45 } \\
\text { cTY47 } \\
\text { cTY53 }\end{array}$ & $\begin{array}{l}11 \\
11 \\
12\end{array}$ & $\begin{array}{l}\text { B } \\
\text { C } \\
\text { B }\end{array}$ \\
\hline TY10 & $\begin{array}{l}\text { cTY67 } \\
\text { cTY69, cTY70,cTY71 } \\
\text { cTY72 }^{\text {a }}\end{array}$ & $\begin{array}{l}- \\
15 \\
17\end{array}$ & $\begin{array}{l}\text { C } \\
\text { B } \\
\text { E }\end{array}$ & & & & \\
\hline
\end{tabular}

a The strains that were able to utilize glucose, lactose, fructose but have variable response for mannose, galactose, sucrose, maltose, melibiose, and raffinose, are phenotypically assigned as typical S. thermophilus and highlighted as red in the table. 


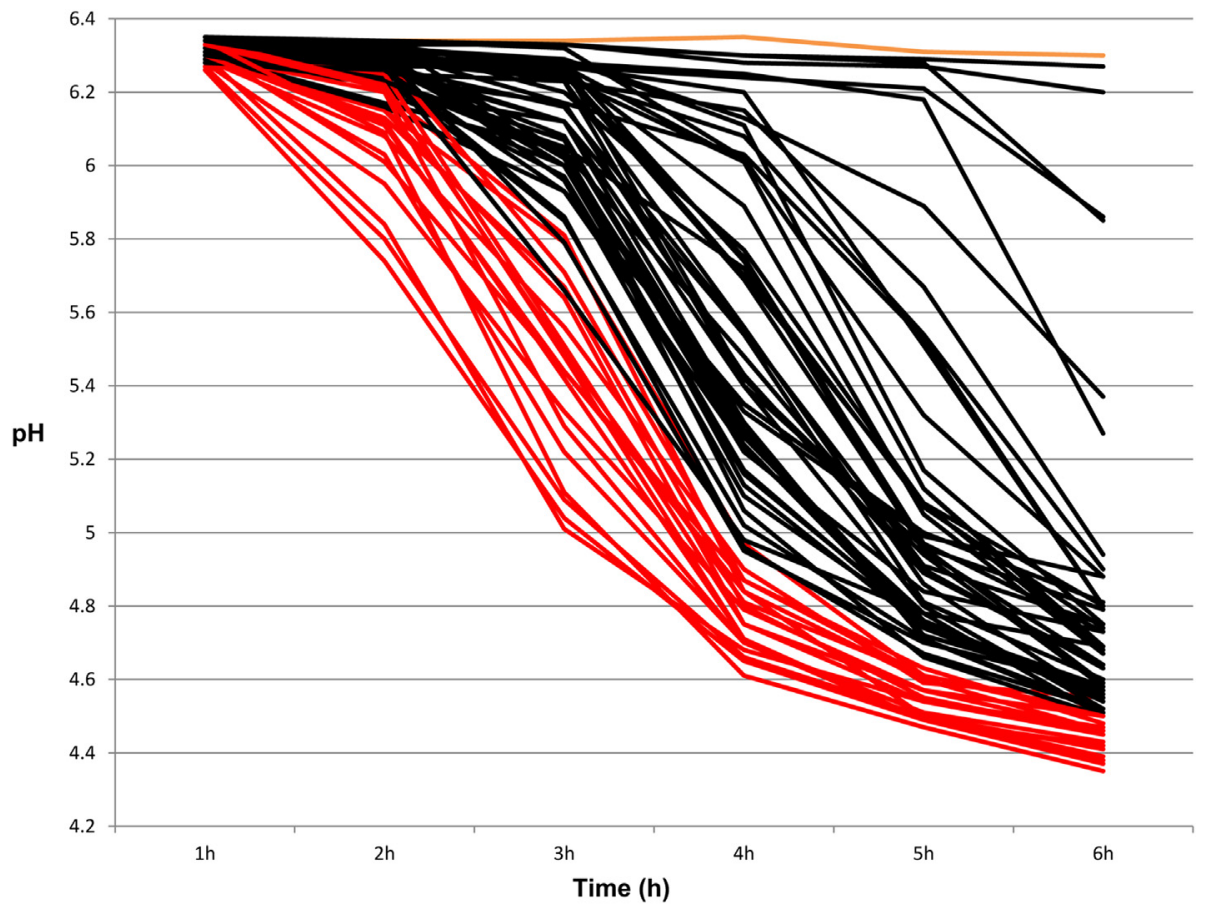

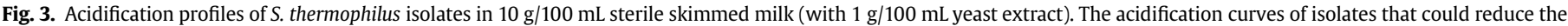

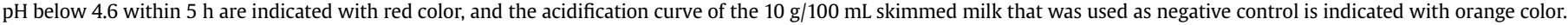
(For interpretation of the references to color in this figure legend, the reader is referred to the web version of this article.)

Dairy factories encounter severe phage predation problems in routine yoghurt fermentations. Therefore, some of the fast acidifying $S$. thermophilus isolates within our isolation set additionally have been studied for phage resistance to have an indication of their robustness against phage attacks by Soydemir (2008, pp. 41). The isolates c95-1, cTY25, cTY55 and cTY63-2 were challenged against $26 \mathrm{~S}$. thermophilus specific phages that were isolated and identified from dairy products (Soykut, 2007, pp. 48). Only 5 out of the 26 phages were reported to be effective on the indicated $S$. thermophilus strains. The most phage resistant strain was determined to be cTY55, for which no plaques were developed for any of the 26 phages, and the most sensitive strain was found to be cTY632 showing vulnerability to 5 different phages.

\section{Conclusion}

The results of species-specific PCR and16S rRNA gene sequencing were consistent with those of the reference $S$. thermophilus strain. PFGE analysis helped to differentiate 61 isolated strains into 22 homology groups (Table 2). Carbohydrate utilization tests provided useful information on the phenotypic diversity and revealed 22 different profiles. Most of the profiles were atypical for S. thermophilus strains, and only 7 of the strains were found to be very similar to $S$. thermophilus type-strain. Comparison of PFGE homology groups with carbohydrate utilization profiles didn't give any overlap and revealed the presence of further phenotypic heterogeneity within PFGE homology groups. Furthermore isolates were further tested for their technological performance to be used as yoghurt starter culture. Majority of the isolates were determined to be protease positive and had fast acidification in milk.

\section{Acknowledgments}

We would like to acknowledge Mert Sudagidan for his scientific assistance during the PFGE study, Elif Sinem Celik for her contribution to the bacterial isolation and further flavor profiling of co- culture growths in her thesis study, Elcin Soydemir for the phage sensitivity tests of the isolates in her thesis study, and Hatice Yavuzdurmaz for her contribution to the bacterial isolation. This study was supported by the Government Planning Institution under the project "The Production of Cheese and Yoghurt Starter Cultures and Lactase Enzyme for the Dairy Industry: Traditional and Modern Solutions against Lactose Intolerance". Prof. Dr. Nihat AKIN is acknowledged for kindly providing yogurt samples that was used for the isolation of microbial species.

\section{References}

Abrahamsen, R. K., Svensen, A., \& Tufto, G. N. (1978). Some bacteriological and biochemical activities during the incubation of yogurt from goat's and cow's milk. In 20th International dairy congress, Paris, IE (pp. 828).

Bogaard, P. T. C. (2002). Catabolite control of sugar metabolism in Streptococcus thermophilus. Dissertation. The Netherlands: Wageningen University. Available from: Wageningen University, Forum; Stacks; NN08202, 3292.

Bottazzia, V., \& Dellaglioa, F. (1967). Acetaldehyde and diacetyl production by Streptococcus thermophilus and other lactic streptococci. Journal of Dairy Research, 34, 109-113.

Bulut, C., Gunes, H., Okuklu, B., Harsa, S., Kilic, S., Coban, H. S., et al. (2005). Homofermentative lactic acid bacteria of a traditional cheese, Comlek peyniri from Cappadocia region. Journal of Dairy Research, 72, 19-24.

Çelik, E. S. (2007). Determination of aroma compounds and exopolysaccharide formation by lactic acid bacteria isolated from traditional yoghurts. Dissertation. Izmir, Turkey: Izmir Institute of Technology. Available from: Izmir Institute of Technology, SF275.Y6 C3928.

Dandoy, D., Fremaux, C., Frahan, M. H. D., Horvath, P., Boyaval, P., Hols, P., et al. (2011). The fast milk acidifying phenotype of Streptococcus thermophilus can be acquired by natural transformation of the genomic island encoding the cellenvelope proteinase PrtS. Microbial Cell Factories, 10, 1-9.

De Vin, F., Radström, P., Herman, L., \& de Vuyst, L. (2005). Molecular and biochemical analysis of the galactose phenotype of dairy Streptococcus thermophilus strains reveals four different fermentation profiles. Applied and Environmental Microbiology, 71, 3659-3667.

Gardini, F., Lanciotti, R., Guerzoni, M. E., \& Torriani, S. (1999). Evaluation of aroma production and survival of Streptococcus thermophilus, Lactobacillus delbrueckii subsp. bulgaricus and Lactobacillus acidophilus in fermented milks. International Dairy Journal, 9, 125-134.

Giraffa, G., Paris, A., Valcavi, L., Gatti, M., \& Neviani, E. (2001). Genotypic and phenotypic heterogeneity of Streptococcus thermophilus strains isolated from dairy products. Journal of Applied Microbiology, 91, 937-943. 
Giraffa, G., \& Rossetti, L. (2005). Rapid identification of dairy lactic acid bacteria by M13-generated, RAPD-PCR fingerprint databases. Journal of Microbiological Methods, 63, 135-144.

Gobbetti, M., \& Corsetti, A. (1999). Encyclopedia of food microbiology. In C. Batt, P. Patel, \& R. Robinson (Eds.), Streptococcus thermophilus: introduction (pp. 2117-2126). United Kingdom: Academic Press.

Herve-Jimenez, L., Guillouard, I., Guedon, E., Boudebbouze, S., Hols, P., Monnet, V. et al. (2008). Post-genomic analysis of Streptococcus thermophilus co-cultivated in milk with Lactobacillus delbrueckii ssp. bulgaricus: involvement of nitrogen, purine and iron metabolisms. Applied and Environmental Microbiology, 75 2062-2073.

Letort, C., \& Juillard, V. (2001). Development of a minimal chemically defined medium for the exponential growth of Streptococcus thermophilus. Journal of Applied Microbiology, 91, 1023-1029.

Letort, C., Nardi, M., Garault, P., Monnet, V., \& Juillard, V. (2002). Casein utilization by Streptococcus thermophilus results in a diauxic growth in milk. Applied and Environmental Microbiology, 68, 3162-3165.

Levander, F., Svensson, M., \& Radström, P. (2002). Enhanced exopolysaccharide production by metabolic engineering of Streptococcus thermophilus. Applied and Environmental Microbiology, 68, 784-790.

Lick, S., Keller, M., Bockelmann, W., \& Heler, K. J. (1995). Rapid identification of Streptococcus thermophilus by primer-specific PCR amplification based on its lacZ gene. Systematic and Applied Microbiology, 19, 74-77.

Lortal, S., Rouault, A., Guezenee, S., \& Gautier, M. (1997). Lactobacillus helveticus: strain typing and genome size estimation by pulsed field gel electrophoresis. Current Microbiology, 34, 180-185.

Millière, J. B., Abidi, F. Z., \& Lefebvre, G. (1996). Taxonomic characterisation of Lactobacillus delbrueckii subsp. bulgaricus isolates from a Cameroonian zebu's fermented raw milk. Journal of Applied Bacteriology, 80, 583-588.

Moschetti, G., Blaiotta, G., \& Aponte, M. (1998). Random amplified polymorphic DNA and amplified ribosomal DNA restriction spacer polymorphism: powerful methods to differentiate Streptococcus thermophilus strains. Journal of Applied Microbiology, 85, 25-36.

Okuklu, B. (2005). Investigation of chromosomal and plasmid profiles of Lactococcus lactis ssp lactis. Dissertation. Izmir, Turkey: Izmir Institute of Technology. Available from: Izmir Institute of Technology, QR121.041 2005.

Pearce, L., \& Flint, S. (1999). Encyclopedia of dairy science. In H. Roginski, J. Fuquay, \& P. Fox (Eds.), Streptococcus thermophilus (pp. 2577-2582). United Kingdom: Academic Press.

Rademaker, J. L. W., Herbet, H., Starrenburg, M. J. C., Naser, S. M., Gevers, D., Kelly, W. J., et al. (2007). Diversity analysis of dairy and nondairy Lactococcus lactis isolates, using a novel multilocus sequence analysis scheme and
(GTG) 5-PCR fingerprinting. Applied and Environmental Microbiology, 73 $7128-7137$.

Robinson, R. K. (2002). Encyclopedia of dairy science. In H. Roginski, J. Fuquay, \& P. Fox (Eds.), Yoghurt, role of starter cultures (pp. 1059-1063). United Kingdom: Academic Press.

Salzano, G., Moschetti, G., Villani, F. G., \& Coppola, S. (1993). Biotyping of Streptococcus thermophilus strains by DNA fingerprinting. Research in Microbiology, 144 $381-387$.

Sieuwerts, S. (2009). Analysis of molecular interactions between yoghurt bacteria by an integrated genomics approach. Dissertation. Wageningen, The Netherlands: Wageningen University. Available from: Wageningen University, Forum; Stacks ; NN08200, 4704.

Soydemir, E. (2008). Determination of whey-based medium requirements and growth characteristics for the production of yoghurt starter cultures. Dissertation. Izmir Turkey: Izmir Institute of Technology. Available from: Izmir Institute of Technology, SF275.Y6 S73.

Soykut, E. A. (2007). Identification and classification of virulent bacteriophages of Streptococcus thermophilus and Lactobacillus bulgaricus based on their replication parameters, capsid protein profiles and restriction endonuclease analysis. Dissertation. Ankara, Turkey: Ankara University. Available from: Ankara University, $10.1501 / 0003228$

Tamime, A. Y., \& Robinson, R. K. (1985a). Yoghurt: science and technology. In A. Y. Tamime (Ed.), Introduction (pp. 1-5). Great Britain: Pergamon Press.

Tamime, A. Y., \& Robinson, R. K. (1985b). Yoghurt: science and technology. In A. Y. Tamime (Ed.), Biochemistry of fermentation (pp. 295-327). Great Britain: Pergamon Press.

Tamime, A. Y., \& Deeth, H. C. (1980). Yogurt: technology and biochemistry. Journal of Food Protection, 43, 939-997.

Terzaghi, B. E., \& Sandine, W. E. (1975). Improved medium for lactic streptococci and their bacteriophages. Applied Microbiology, 29, 807-813.

Vaillancourt, K., LeMay, J. D., Lamoureux, M., Frenette, M., Moineau, S., \& Vadeboncoeur, C. (2004). Characterization of a galactokinase-positive recombinant strain of Streptococcus thermophilus. Applied and Environmental Microbiology, 70, 4596-4603.

Vaughan, E. E., Van Den Bogaard, P. T. Catzeddu, P., Kuipers, O. P. \& de Vos, W. M. (2001). Actiation of silent gal genes in the lac-gal regulon of Streptococcus thermophilus. Journal of Bacteriology, 183, 1184-1194.

Yeung, P. S. M., Kitts, C. L., Cano, R., Tong, P. S., \& Sanders, M. E. (2004). Application of genotypic and phenotypic analyses to commercial probiotic strain identity and relatedness. Journal of Applied Microbiology, 97, 1095-1104.

Zirnstein, G., \& Hutkins, R. (1999). Encyclopedia of food microbiology. In C. Batt, P. Patel, \& R. Robinson (Eds.), Streptococcus thermophilus (pp. 2127-2133). United Kingdom: Academic Press. 